\title{
Mortuary Mentalities in Ancient Egypt
}

\author{
Eric de Payen \\ Fu-Jen Catholic University, New Taipei City, Taiwan
}

\begin{abstract}
There is almost no work on ancient Egypt in Taiwan since historians are logically interested in ancient China. Egyptologists either work on archeology or study papyrus and written texts found in pyramids and tombs, without putting it in perspective with other civilizations, such as Greek civilization. Philippe Ariés’ global history offers innovative opportunities on the study of Egyptian mentalities. All traditional historical work aims to study an ancient society, a social class, but very few focuses on the individuals. The theses of Lucien Febvre, father of the notion of mentalities, allow the historical discipline to have access not only to the factual structures of societies but also to the mental structures of the individuals that compose it. This new approach raises a crucial question: What are Europe's roots? Has the Egyptian heritage been underestimated?
\end{abstract}

Keywords: ancient Egypt, Philippe Ariès, mentalities, death

Every culture, group, or individual has a memory: A historical accumulation from which the world in which we live is interpreted. All the anxieties or hopes living within us carry with them ancient myths, sometimes unknown to the modern man. According to Lévi-Strauss, myths are at the root of every civilization and while some are specific to each society; others have crossed time and the borders of their societies of origin: They are called "root myths", i.e., mythical and universalized foundations that go from people to people, maintaining a more or less identical core argument, with script distortions, changes in the names of the characters, and their secondary attributes. In these myths, the presence of gods and their actions is observed.

This structure is both internal and the result of external influences, more diffuse and therefore less commented by historians. The overly scientific aspect characterizing the history of the last two centuries has stood in the way of seeing that civilizations are not only explained by political and economic facts but also by values that we will qualify as "sensitive" (referring to the emotional aspect). After a long and unfinished controversy, historians are now beginning to accept two important ideas: Emotions are sometimes more essential than science to explain a civilization and we must look beyond Greece, in this case in Egypt, to understand the origins of some European values.

If there is one point on which each civilization develops a whole cultural and religious knowledge, it is the funeral rituals. Humans are the only species who takes care of their deceased. It is a sign of his humanity. Since prehistoric times, he/she has been burying his/her dead. The first human civilizations relied on the idea that together, each individual could protect himself/herself from external dangers but also, with the help of deities, each individual could protect himself/herself from the annihilation of death. The sociologist Jean Cazeneuve wrote: "A society devoid of any ritual would be an anomaly".

Eric de Payen, Ph.D. in History, Associate Professor, College of Foreign Languages, Fu-Jen Catholic University, New Taipei City, Taiwan. 
Egyptian papyruses, like the Book of the Dead, are the most relevant sources in order to present funeral mentalities in Egypt. Hence, we can understand how the Isiac cults (dedicated to the goddess Isis) have allowed the spread of rites related to the god Anubis all around the Mediterranean Sea. Shrines dedicated to Anubis are listed throughout Western Europe. Contemporary texts mention that shrines dedicated to Anubis had existed in the present-day cities of Arles or Nîmes.

Egyptologists either work on archeology or study papyrus and written texts found in pyramids and tombs, without putting it in perspective with other civilizations, such as Greek civilization. Philippe Ariés’ global history offers innovative opportunities on the study of Egyptian mentalities. All traditional historical work aims to study an ancient society, a social class, but very few focuses on the individuals. The theses of Lucien Febvre, father of the notion of mentalities, allow the historical discipline to have access not only to the factual structures of societies but also to the mental structures of the individuals who compose it. This new approach raises two crucial questions: Can we better comprehend an ancient civilization through the history of mentalities? Is the theme of death a way to better understand Egyptian mentalities?

\section{The History of Mentalities and the Book of the Dead, a Study of the Mortuary Mentalities of Egyptians}

Philippe Ariès is the greatest French historian who has worked on mentalities, particularly through the theme of death. How can we talk about such a highly sensitive subject and do these tools allow us to study ancient Egypt from a different perspective?

\section{The History of Mentalities According to Philippe Ariès}

Philippe Ariès' book, which serves as a reference is L'Homme devant la mort (1977) in which he reveals his working methods. "The observer reviews a heterogeneous (rather than homogeneous) amount of documents, and tries to decipher, beyond the will of writers or artists, the unconscious expression of a collective sensitivity" (Gros, 2013, p. 13).

Consequently, Ariès uses several documentary corpora: literary, liturgical, testamentary, epigraphic, and iconographic. The history of mentalities is not conceived as a chronological study, but as a thematic analysis with a cognitive focus. Let us take the example of death, which concerns this research, where Philippe Ariès identifies four aspects:

(1) Tamed death. Death is not only an individual matter because it is commemorated by ritualized collective ceremonies. The community seeks to ensure its continuity and stability. The dying person accepts it and takes part in it for religious reasons (saving his/her soul, guaranteeing his/her passage to a paradisal world...) or for social reasons (allowing his/her family and his/her loved ones to assist him/her in his/her last moments).

(2) One's own death. Existential issues are one of the foundations of the human being: the awareness of one's own mortality and the ability to find a way to overcome it. Through religions, mankind has provided an almost universal solution: If physical death is a fact, the soul continues to exist in the afterlife.

(3) Thy death. The psychological crisis caused by the death of someone close is often more devastating on the psychological level than fear of one's own death. We have here a romantic exaltation of death which is one of the richest sources of literature. It also explains the worship of tombs and the visits of cemeteries. Despite popular belief, cemeteries have a much greater social meaning for the living than for the buried dead. 
(4) Forbidden death. It is the modern negation of the first three deaths. The dying person no longer manages its own death; it is in the hands of relatives, doctors, and society. This is the major shift in modern civilizations. Death is no longer part of life; it is rejected, entrusted to others, such as the community and God.

For this reason, an actual individual of today has a relationship to death that is understood thanks to the whole history of death in the same geographical area.

We find traces of accumulations, but the entire story is there. So, can we affirm that, in all Mediterranean civilizations, it is inevitable to find traces of attitudes towards death inherited from ancient Egypt? Let us test this hypothesis by opening the Book of the Dead, the "Bible" for Egyptian civilization.

\section{A Historical Study of Egyptian Mortuary Mentalities}

For historians specializing in ancient civilizations, most of the original texts remaining speak about the social representation of death and the afterlife. This is particularly the case in ancient Egypt.

For Egyptians, whose civilization traversed three millennia before Jesus Christ, life after death was a tangible reality, as evidenced by the Book of the Dead, also known as the Book of Coming Forth by Day. The Egyptians who were wealthy enough must have had a copy of the Book of the Dead in their graves because it helped the deceased. Nearly 200 spells were used to make up the sroll, which could measure up to 25 meters in length. It is not a uniform text written in one go. It is an aggregate of spells added over the centuries, showing both the increasing complexity of Egyptian religiosity and their extremely rich cultural and literary heritage. The oldest should date back to the 17th dynasty (about 1600 BC). For modern readers, The Book of the Dead cannot be considered as pure religion because the very principle of religiosity in a polytheistic society has nothing to do with our monotheistic society. According to our criteria, it included religious as well as magical content. Egyptologist François Lexa wrote that "In magic, mankind believes in his own power to fight against the difficulties and dangers that threaten him” (Toutain, 1929, p. 127) in his life on earth and in the afterlife.

In the Book of the Dead, there is a key moment in the deceased's journey to the afterlife: the weighing of the soul. This idea of final judgment, which will be taken up by Christianity, reinforces the point that death must be prepared. Philippe Ariès saw in this moment two of the four aspects of death, tamed death and one's own death where mankind prepares its physical death and its continuity in the afterlife. A feather, symbol of the goddess of Justice Ma'at, was put on one side of the scale and the soul of dead was placed on the other side (psychostasy). To ensure that the soul is lighter, the Book offered the deceased a whole list of spells designed to show the purity of the one who recites them. There is a major difference here with Christianity. When a Christian dies, he/she must repent and confess all his/her sins. Merciful God forgives all those who confess sincerely. The Egyptian religion does not work that way at all. The deceased must be pure upon arrival. Therefore, we find again the fundamental notion of preparation. Mankind prepares its death during its life on earth and, to do so, it must respect the will of the gods. According to the Egyptians, the one who has been honest and a good believer cannot fear death. He/She could peacefully follow the spells set out in the Book of the Dead, namely the first concerning all the faults not committed to prove his/her virtue to the judges. Who are they? First of all, there is Anubis, represented as a jackal-headed man, who prepares the dead man for his judgment. Afterwards comes Thoth, depicted as a man with the head of an ibis, who will write all the statements made at that moment. Horus finally presents the dead to Osiris, who reigns over the realm of the dead. 
Today, there are "four texts considered as the greatest religious teachings: the Negative Confession of the Egyptian Book of the Dead, the Decalogue of Moses, the Beatitudes of Christ and the Four Noble Truths of the Buddha" (Bancourt, 2001, p. 4). One of the greatest differences between these texts is probably the presentation of man's own morality. The "negative confession" is said to be the proclamation of innocence that the deceased recites before the court of Osiris to show that his virtuous soul deserves salvation. The primary goal of religions is to teach people to differentiate between good and evil. The Egyptian Book of the Dead conveys the oldest conception of the good in human history that has come down to us. The spells set out by the deceased seem to be childish or at least naive for a modern public. Many commentators have been tempted by moral criticism, forgetting the ultimate blasphemy that the historian is fighting: anachronism. That is why the French Egyptologist Gaston Maspero, a member of the Académie des inscriptions et belles-lettres, wrote directly and without any stylistic tact that the confession of Egyptians "is a naive process" (Maspero, 1893, p. 345) and, while pursuing his stereotypes, wrote that all ancient civilizations were in the same state of mind. Some historians forget the lesson of structuralism, which has proved that everything begins with linguistics. In that case, the weight, the value and the cultural and cognitive dimension of words must be taken into account and what seems naive to us today was once sacred. Finally, the terror felt by modern civilization in towards death would also seem probably childish for an Egyptian. These statements aim to highlight what the history of mentalities considers to be one of its foundations: to describe and analyze feelings or emotions, without ever appropriating them.

Another anachronism based on a stereotype remains persistent: By definition, the polytheist religions are animistic and, therefore, considered as less "serious" than monotheistic religions based on more intellectual philosophies and beliefs. Yet, the Egyptian heritage shows that this civilization has reached such a level of religiosity that we do not yet understand all its subtleties. We must objectively learn to understand Egyptian mentalities and go beyond the simple reading of words. Consequently, when in these Negative Confessions, it is forbidden to steal offerings brought to the gods; it is not simply a matter of theft, but more specifically a desire not to cause a rupture in the supply of energy to the dead in the afterlife. Whereas modern civilizations see material affirmations, the Egyptians see a spiritual affirmation.

The approach to writing must also be taken into account. If, for French people, writing is often synonymous with the expression of a logical and clear idea; for Egyptians, writing is a means of communication and, very often, the person who recites does not always have a precise understanding of what he is reading. Indeed, words had magical virtues at that time that favor an interaction with and in the afterlife. The academician Alfred Maury tells in his book (Maury, 2016) that Greek philosophers were offended that the Egyptians could believe that simple words described as magic could give orders to the gods. Many ancient texts have a particularity that lies in the use of myths and symbols, to which their meaning must be restored. For centuries, Egyptian writing and texts remained unreachable and then, after mastering hieroglyphs, it was necessary to decipher sentences that were often nebulous and obscure. With the spread of the history of mentalities, the historian has better cognitive tools to understand their meaning.

We thus understand that the Book of the Dead is more than a spiritual guide; it is also a manual for educational use. Since the Third Republic, we have known in France the central role of the school in training young people to become citizens who vote and who are part of a national community, a civilization. The Book of the Dead therefore played an even more important role than expected in the formation of Egyptian civilization. We can then ask ourselves whether the way of perceiving death is the foundation of a civilization 
because it is the encounter not only of mentalities but also of a social, religious, and political organization. "The Book of the Dead proposes an initiation to achieve a true transmutation” (Molinié, 2010, p. 128). From there on, the human being then becomes one and many at the same time. It retains its specificity while belonging to the universe. He is the incarnation of the goddess Ma'at who symbolizes order and balance. Keywords appear that set a lexical field of transmutation, such as salvation, deliverance, liberation, and immortality. This initiatory education was lost after antiquity and is one of the greatest intellectual losses that neither religious schools nor universities have been able to compensate for. The lack of this knowledge in modern university education has an inherent difficulty due to a spirituality that has been extinct for several millennia, despite the spread of fragments in later civilizations. As Philippe Ariès stated, mentalities fit in a collective unconscious, so how can we extract their essence through the use of rational scientific tools? The few sources available come directly from ancient writings. However, their authors use a language appropriate to the time and to religious subjects. Their deliberately veiled and incomplete allusions do not allow us to reconstruct the modalities of the Egyptian initiation with precision and certainty. Philippe Ariès had defined that history cannot be seen as chronological stages without any link with each other but as a whole. Therefore, the postulate regarding the universality of an esoteric fund common basis to Egypt and later Mediterranean civilizations is plausible. Accordingly, despite what Egyptologists believe, it is not impossible to find in European civilization traces of Egyptian mentalities hitherto forgotten. In anthropology, Lévi-Strauss had stated that all societies are based on the family, a common element that seems undeniable today. Are there other common elements resulting from knowledge that can be qualified as esoteric instead of religious? Modern human sciences allow new approaches to ancient Egypt.

\section{History Against Psyche, New Approaches in the Study of Egyptian Mentalities}

Among the greatest influences that have extended through historical sciences, the psyche and the unconscious have been a revolution. Now, let us look at how the historian can include psychoanalysis and psychology, particularly to understand better ancient mentalities.

\section{An Opening of the History of Mentalities to Jungian Psychoanalysis}

Psychoanalysis can perfectly complement Philippe Ariès’ work in his attempt to understand the meanders of Egyptian thought. Jung's research on the collective unconscious creates a common notion with the history of mentalities. When you look at the illustrations in the Book of the Dead for the first time, it is like reading a fable of La Fontaine. One of the fundamental differences is that, in a fable by La Fontaine, each animal has a main characteristic that makes it good or evil while, in the Book of the Dead, the same animal can be either a god or a demon. We have various examples, such as the snake or the crocodile.

By comparing Egyptology and psychoanalysis, the reader questions the psychological and historical aspects of the interpretation of texts, images, or social representations. Jung's first observation is that, in this day and age, the soul is internalized, because it is psychologized, but in Egyptian civilization, it is also externalized and has its own independent motor. Jung says Egypt has a "grandiose religion” (Liard, 2007, p. 51) at least as complex as Christianity, which will appear later. When history and psychoanalysis can be combined on the theme of mentalities and a collective unconscious, we observe, under the so-called childish Egyptian texts, the emergence of a mythology and a religiosity of great subtlety whose fundamentals the modern Western world has not yet begun to perceive. 
Jung took the study of Egyptian mentalities a step further by taking care not to make the same mistakes as many Egyptologists: taking into account writing in its contemporary context. This study includes several levels: linguistic, cultural, and cognitive. Egyptologist François Chabaud, as part of his Ph.D. thesis (2012), took up Jung's work to attempt an analysis of hieroglyphs. Signs or ideograms (pictures), phonograms (sounds), engravings (touch), vibrations (the Horus wave in ancient Egypt, the impulse in Freud) represent the four articulations of the Egyptian language. The objective is to trigger a psychological reaction within the reader that links a symbol to an object. By its origin, Egyptian writing is linked to the need to create religious texts, hence this approach of ideas both concrete and abstract expressed by hieroglyphs. Moreover, the etymology of this word in Greek means "sacred engraving", which clearly indicates the link between the very essence of the hieroglyph and religion.

The linguistic aspect lying in the issue of understanding hieroglyphics to better comprehend semantics is completed by another question: How to translate what is difficult to define clearly? Modern translators have great difficulty with hieroglyphs because they must be perceived differently from languages with alphabet. For this reason, there is no punctuation, which is difficult for the French speaker to conceive. The translator can only imagine sentence breaks or groups of words, which inevitably leads to significant risks of misinterpretation. Similarly, the conjugation is almost unidentifiable: Sometimes, the translator cannot perceive if the text is written in the past, the present or the future. It is all about contextualization. Again, there is a great risk of misunderstanding these ancient texts. The translator is almost forced to neglect linguistics in order to analyze first the idea and formulation habits of other texts. To do so, it is necessary to have a good knowledge of Egyptian mentalities in order to anticipate the word associations in a sentence about cultural, social, political, or religious notions. In the end, there is no official and definitive translation of the texts written in hieroglyphs, since each of them is different.

After the linguistic aspect, the cultural and cognitive aspects prevail thanks to the work of the psychoanalyst Roland Khater on the deciphering of the Book of the Dead of Egypt (Khater, 2011). The author reveals the psychological meaning of the different deities and analyses their interactions as psychological parameters. Roland Khater was one of the readers frustrated by the apparent lack of logic present in the Book of the Dead's translation. In his book, he describes that one day when he was working on the psychological entities, he modified the famous Freudian definition to come with a new theory of a self with two tendencies: the coherent-self and the ego-self. According to Freud, the self is the result of a tension between the id and the superego, whereas Khater sees in it a division of the self between the id (that we link to the ego-self) and the superego (coherent-self). The theory is not different in the meaning, but in the links that structure it. In other words, Freud features three separate entities whereas Khater only sees one, with two subdivisions. The main consequence of Khater's approach is to accentuate the role of the self in the psychological system while accentuating the psychological duality (good and evil). We know that Freud based his work on Greek myths, such as Oedipus. Once this rewriting completed, Khater did the same and realized that it fits perfectly into Egyptian myths. He notices in the opposition between the gods Horus and Seth the same opposition found between the two "selves" of his psychoanalytical theory. With this input, a new reading is possible.

Indeed, the Book of the Dead leads the reader to make an introspection and to question his/her deep self. The Book gives no moral lesson and the gods do not threaten mankind, they act only according to the life that each one had, virtuous or not. In later mythologies and in Christianity, there is a paternal role, with its excesses. However, the Egyptian's real fear was to die a second time, to see his/her inner awakening destroyed. "I will 
not die a second time" (excerpt from chapter 44 of the Book of the Dead). This notion of a second death will be transmitted in the Apocalypse of Saint John: "But as for the cowardly, the faithless, the polluted, the murderers, the fornicators, the sorcerers, the idolaters, and all liars, their place will be in the lake that burns with fire and sulfur, which is the second death”. We observe that each individual is totally self-centred. In Egypt, everything is focused on this fear while, in Christian Europe, other considerations are also taken into account. There is therefore a transmission from Egypt to Europe on this matter, even if transformations in the dogma are visible.

While modern monotheistic religions base their dogmas on repentance and reward, the Egyptian prefers to work on himself/herself to be worthy of saving, which constitutes a true psychoanalytical approach. Similarly, if prophets, such as Moses or Jesus serve as a link between God and men, the Egyptian religion adopts the path of perfection through initiation.

Accordingly, the gods and goddesses of the Book of the Dead represent psychological desires that help mankind to develop his/her inner awakening and to evolve towards deification. The importance of the Egyptian religion is that it has been able to identify, according to Roland Kather, key desires that form the structure of what Freud calls the psychic apparatus. Demons (2016) represented destructive desires and promoted chaotic states of consciousness. They bring the individual to move towards his/her second death, the real one. The Book of the Dead makes the reader aware of the relationship between the mental and bodily dimensions and encourages him/her to give priority to informative values over material pleasures. The Book would therefore be similar to one of our prayer books.

\section{The Psychological Approach to the Historical Study of Emotions}

As we have noticed, in Egypt, death is both a collective and an individual issue. We are now familiar with social rituals, the psychological (not to say psychoanalytical) aspect comes second. Egyptologist Jan Assman has made an interesting study for a historian of mentalities. He begins his book like this: "Man is the animal that must live knowing that it is mortal and culture is the world that man builds to be able to live with this knowledge" (2003, p. 2). The death of Osiris mythologically marks the arrival of death into the world. Osiris was murdered by his brother Seth. Isis, his wife, reconstructs his body and resurrects it. However, he will have to remain in the afterlife. Assman sees in this myth the three images of death: "death as an enemy, death as a return to origin and death as a mystery” (1998, pp. 169-173). If death is an enemy and we suffer injustice, then we ask for reparation before the court of the gods. It is from this reflection that the idea of judging the deceased has gradually emerged. One of the most famous scenes in Egyptian mythology, which represents the weighing of the deceased's soul in the presence of the god Anubis, is no longer only justified by social considerations but by a psychological necessity to accept death, always experienced as a profound injustice.

As for death as a return to origin, Jan Assman considers it as such an old concept that it is difficult to define it. The French anthropologist Lucien Lévy-Bruhl spoke of primitive mentalities while Jung talked about the archaic unconscious. This notion of death represents the existence within a circle with birth, death, and rebirth in the midst of a genitor whom some now call the universe or God and whom the Egyptians represented as the goddess Nut. This very psychoanalytical aspect of death allows, after the enemy death represented by Anubis, to better understand death as a return to the origin represented by Nut.

Finally, the mystery of death is the idea that mankind must accept not to understand everything. In the Egyptian religion, the sacred is close to secrecy. There is a veiled goddess, some see Isis, mother of gods and mortals that no one can see and whose function is to veil the dead. This vision traces one of the mankind 
greatest existential anxieties: What happens after death? We do not know it, the only thing we know is that someone is there (Isis?) to veil the corpse and give us the signal of the beginning of our path to the afterlife.

The theatricalization of death allows a transfer from a personal tragedy to a social tragedy. Hence, because it is first a matter of individual emotion, death becomes afterwards a matter of collective emotion. The whole aspect of psychological origin was missing in the explanation of many Egyptologists who tend to always study everything through social structures. Theatricalization, this word has taken on a negative connotation today, implying exaggeration or irrational behavior. In this case, we see an opposition between the rational resulting from the rupture of Greek philosophy and the mentalities of Egypt which encompass the whole variety of emotions. Thus, there is no analytical opposition but an approach, the Greeks preferring reflective thought to immanent thought (in the sense that it is sufficient in itself).

In the myth of Osiris, his murder is experienced as a cosmic catastrophe. Consequently, each individual can then experience the death of one of his/her own with the same magnitude. Seth embodies the death he unjustly gives and which must be criticized and strongly condemned. If, in modern ceremonies, the relatives of the deceased must show dignity and restraint by trying to internalize their grief; it is quite the opposite in Egyptian society where not mourning the deceased would be frowned upon: By extrapolation, it would mean not mourning Osiris' death. The Belgian Egyptologist Marcelle Werbrouck (1938) had carried out archaeological work on Theban tombs dating from the 17th dynasty. We can observe drawings on them on which emotions are highlighted in detail: raised arms, lamentations, bare breasts.... Consequently, when people cry at funeral ceremonies, it cannot be considered vulgar because it reminds Isis' lamentations.

Egyptologist Pascal Vernus published a book entitled Chants D’amour de L'Egypte Antique (1992). He tries to demonstrate what literature meant to the Egyptians. He defines it as beautiful letters, in other words, texts with a beautiful stylistic twist. At that time, literature was essentially oral. It is only halfway through the history of Egypt that the writings really began to spread. He notes with interest that Egyptian love songs and funeral songs are written in the same tone and style. Crying over a deceased and desiring his/her presence are seen as two sides of the same coin. The emotion for one of the psychological states calls on the other and vice versa. Thus, expressing love is like expressing pain. The Egyptian would then see in the absence of pain a lack of love. Very often, showing these emotions is associated with women, which is not the case in ancient Egypt. Men also have a role to play. Egyptologist François René Herbin (1994) described in Le Livre de Parcourir L'éternité, this traditional scene where men have their limbs covered with dust and sing complaints aloud.

To conclude this research, we have observed that the contribution of Philippe Ariès' work has been considerably useful to archaeologists and specialists in Egyptian antiquity. From a political and social history, or simply put from a collective one, we move on to a history of mentalities where the individual and the society are intertwined. Feelings and emotions, long labelled as purely literary, become tools for historians. Indeed, ancient texts are generally not treaties or laws, but myths. The scientific history transmitted to us by ancient Greece has revealed its limits in terms of talking about civilizations prior to Greece. Philippe Ariès allows us to break taboos, such as chronology or events and to move on to a study of the unconscious. Today, ancient Egypt opens its doors to us and we better understand its messages. Among them, the way of apprehending, preparing and accepting death would be of great help to us. It is a distant past, while at the same time, a part of our future because mankind will be spiritual or will disappear. 


\section{Conclusion}

In the Egypt of the Pharaohs, death is not a taboo, it is a transitional state to survival after physical death. This is why the Egyptians spent a lot of time preparing for the funeral rites and practicing the mummification of the bodies. They built gigantic tombs, the pyramids. Historians know the Egyptian society through two categories of texts: religious and biographical. These writings demonstrate the priority for the ancient Egyptian civilization to prepare well for its physical and social death. Religious texts guarantee this passage to eternal life and biographies help to preserve the memory of the great personages. In ancient Egypt, writing is considered to have the power to bring into existence what it names, and conversely those who were erased are punished with a oblivion.

The theatricalization of death makes it possible to transfer a personal tragedy to a social tragedy. Therefore, death, because it is primarily a matter of individual emotion, then becomes a matter of collective emotion. The psychological origin was lacking in the explanation of many Egyptologists who always tend to see everything through social structures. Theatricalization, this word has taken on a negative connotation today, implying an exaggeration or irrational behavior. We see here an opposition between the rational stemming from the rupture of Greek philosophy and the mentalities of Egypt that encompass all emotions. The next step in this research will be to see how, in funerary rituals, clothing brings its own dimension to the emotions expressed by the Egyptians in front of death.

\section{References}

Abastado, C. (1979). Mythes et rituels de l'écriture (Myths and rituals of writing). Bruxelles: Complexe.

Ariès, P. (1977). L'Homme devant la mort (Man in the face of death). Paris: Le Seuil.

Assmann, J. (1998). Conférence de Mr Jan Assmann École pratique des hautes études (Conference by Mr Jan Assmann EPHE). Section Des Sciences Religieuses, 111(107), 169-173.

Assmann, J. (2003). Mort et au-delà en Egypte ancienne (Death and beyond in ancient Egypt). Paris: Broché

Bancourt, P. (2001). Le livre des morts des égyptien: Livre de vie (The Egyptian Book of the Dead: The Book of Life). Paris: Editions Dangles.

Benoist, S. (2007). Mémoire et histoire: Les procédures de condamnation (Memory and history: Sentencing procedures). Nancy: Centre Régional Universitaire Lorraine D’histoire.

Bercé, Y. M. (1995). L'Histoire et le métier d'historien (History and the profession of historian). Paris: Les Editions de la MSH.

Bloch, M. (1949). Apologie pour l'Histoire ou Métier d'Historien (Apology for History or the profession of historian). Paris: Armand Colin.

Chabaud, F. (2012). La fonction analytique, Freud, Jung et Lacan (The analytic function, Freud, Jung and Lacan) (thèse de doctorat, Montpellier).

Chamoux, F. (1994). L’Egypte d'après Diodore de Sicile (Egypt after Diodorus of Sicily). Actes du 5ème colloque de la Villa Kérylos à Beaulieu-sur-Mer (Proceedings of the 5th conference of Villa Kérylos in Beaulieu-sur-Mer), 6 au 9 octobre 1994, Cahiers de la Villa Kérylos.

Champollion, J. J. (1839). Egypte ancienne (ancient Egypt). Firmin Didot Frères.

Chelzen, O. (2012). Apologie pour Marc Bloch, La Vie des idées (Apology for Marc Bloch, The Life of Ideas). Paris: Hermann.

Damon, J. (2016). 100 penseurs de la société (100 thinkers of society). Paris: Presses Universitaires de France.

Dosse, F. (2005). Les courants historiques en France (The history periods in France). Paris: Armand Collin.

Elloue-Engoune, A. (2016). Laurent-Marie Biffot: Le pionnier de la recherche en sciences sociales (Laurent-Marie Biffot: The Pioneer of Social Science Research). Paris: L'Harmattan.

Febvre, L. (1962). Pour une histoire à part entière (For a specific history). Paris: SEVPEN.

Gros, G. (2013). L'Histoire de la mort peut-elle aider à apprivoiser la mort ? (Can the History of Death help tame death?). Retrieved from http://philippe-aries.histoweb.net 
Herbin, F. R. (1994). Le livre de parcourir l'éternité (The book to travel through the eternity). Louvain: Peeters Publishers.

Hertz, R. (1928). Contribution à une étude sur la représentation collective de la mort. Sociologie religieuse et folklore (Contribution to a study on the collective representation of death. Religious sociology and folklore). Paris: Les Presses Universitaires de France.

Hulak, F. (2008). En avons-nous fini avec l'histoire des mentalités? (Have we finished with the history of mentalities?). Philonsorbonne, 2, 89-109.

Khater, R. (2011). Décryptage de la religion de l'Egypte ancienne (Decoding the religion of ancient Egypt). Paris: Mon petit Editeur.

Légifrance. (2005). Retrieved from https://www.legifrance.gouv.fr/eli/loi/2005/4/22/SANX0407815L/jo/texte

Leloup, J. Y. (2009). Les livres des morts (The books of the dead). Albin Michel.

Liard, V. (2007). Carl Gustav Jung, Kulturphilosoph (Carl Gustav Jung, cultural philosophy). Paris: Presses Paris Sorbonne.

Marchand, J. J. (1977). P.Ariès et le sens des structures (P. Ariès and the meaning of structure). Paris: Contrepoint.

Martin, J. C. (2013). Derrida: Le démantèlement de l'Occident (Derrida: The dismantling of the West). Paris: Max Milo.

Maspero, G. (1893). Etudes de mythologie et d'archéologie égyptiennes (Studies of Egyptian mythology and archeology) (Vol. 1). Paris: Editions Leroux.

Maury, A. (2016). La magie dans l'Antiquité et au Moyen-Age (The magic in Antiquity and the Middle Ages). Paris: Ligaran.

Molinié, A. M. (2010). Mémoires d'Egypte (Memories of Egypt). Paris: Publibook.

Panckoucke, C. L. F. (1826). Description de l'Egypte (Description of Egypt). Paris: Imprimerie Panckoucke

Raymond, P. (1982). Résistible fatalité de l'Histoire (Resistible fatality of history). Paris: Albin Michel.

Toutain, J. (1929). François Lexa. La Magie dans l’Égypte antique de l’Ancien Empire (Magic in Ancient Egypt of the Old Kingdom). Journal Des Savants (Journal of the scholars), 3(1), 126-134.

Vernus, P. (1992). Chants d'amour de l'Egypte antique (Songs of love from ancient Egypt). Paris: Imprimerie Nationale.

Volokhine, Y. (2008). Tristesse rituelle et lamentations funéraires en Egypte ancienne (Ritual Sadness and Funerary Lamentations in Ancient Egypt). Revue de L'Histoire Des Religions (Review of The History of Religions), 2, 163-197.

Werbrouck, M. (1938). Les pleureuses dans l'Egypte ancienne (The mourners in ancient Egypt). Bruxelles: Editions de la Fondation reine Elisabeth. 